Research article

urn:1sid:zoobank.org:pub:22EF1EE7-D663-4795-8FF6-B5C5ABF555DA

\title{
Four new species of Xiphocentron Brauer, 1870 (Trichoptera: Xiphocentronidae) from the Atlantic Forest, southeastern Brazil
}

\author{
Albane VILARINO ${ }^{1, *}$, Bruna Maria Silva CAVALCANTE ${ }^{2}$, \\ Leandro Lourenço DUMAS ${ }^{3} \&$ Jorge Luiz NESSIMIAN ${ }^{4}$ \\ ${ }^{1}$ Faculdade de Filosofia, Ciências e Letras de Ribeirão Preto, Universidade de São Paulo, \\ Av. dos Bandeirantes, 3900, CEP14040-901, Ribeirão Preto, SP, Brazil. \\ ${ }^{2,3,4}$ Departamento de Zoologia, Instituto de Biologia, Universidade Federal do Rio de Janeiro, \\ Caixa Postal 68044, Cidade Universitária, 21941-971, Rio de Janeiro, RJ, Brazil. \\ *Corresponding author: albanevilarino@gmail.com \\ ${ }^{2}$ Email: bmsilva.bio@gmail.com \\ ${ }^{3}$ Email: 1ldumas82@gmail.com \\ 르ail: jnessimian@gmail.com \\ ${ }^{1}$ urn:1sid:zoobank.org:author:44216FF8-7A20-499F-969F-0A626D8425AF
${ }^{2}$ urn:1sid:zoobank.org:author:7C9D157E-B681-4372-88DB-F79EE3A551EB
${ }^{3}$ urn:1sid:zoobank.org:author:55D870A2-6CE2-492E-8E05-2077D5C0CB11
${ }^{4}$ urn:1sid:zoobank.org:author:6FF1B417-72F2-4E5C-84C9-28D58B6A762F
}

\begin{abstract}
Four new species of Xiphocentron (Antillotrichia) Brauer, 1870 from the Atlantic forest are diagnosed, described and illustrated. All of them have a small mesal sclerite and a set of spines, differing in size, density and position, on the inner face of the inferior appendage. Moreover, tergum IX varies mostly in the shape of the posterior margin. Four species are described as new for science. Xiphocentron (Antillotrichia) copacabana sp. nov. is distinguished mainly by the projected basoventral margin of the inferior appendage, the spines are clustered in two regions and the quadrate posterior region of tergum IX. Xiphocentron (Antillotrichia) maracanan sp. nov is differentiated by the inferior appendage, with a strongly angled apical region of $90^{\circ}$. Xiphocentron (Antillotrichia) redentor $\mathrm{sp}$. nov. differs by the inferior appendage, with a linear row of thick spines, and the tergum IX, with a posterior margin forming smoothly rounded lobes. Xiphocentron (Antillotrichia) tijuca sp. nov. is diagnosed by the subbasal region of the preanal appendage, which is markedly projected medially, and by the inferior appendage, which is thin subapically, enlarged apically and strongly bent dorsad.
\end{abstract}

Keywords. Aquatic insects, Annulipalpia, caddisflies, Neotropical, taxonomy.

Vilarino A., Silva Cavalcante B.M., Dumas L.L. \& Nessimian J.L. 2018. Four new species of Xiphocentron Brauer, 1870 (Trichoptera: Xiphocentronidae) from the Atlantic Forest, southeastern Brazil. European Journal of Taxonomy 441: 1-16. https://doi.org/10.5852/ejt.2018.441

\section{Introduction}

The family Xiphocentronidae Ross, 1949, primarily pantropical in distribution, comprises 178 species distributed in seven genera, being especially diverse in Southeast Asia and Central America. The family 
was erected by Ross (1949), but it was synonymized with Psychomyiidae Walker, 1852 by Edwards (1961), based on larval similarities, and treated as a subfamily of Psychomyiidae for many years. Schmid (1982) re-established the family status of Xiphocentronidae in a worldwide revision of xiphocentronids, based on the distinct male genital characters, in which the segment $\mathrm{X}$ is ventrally closed, supporting an extremely elongated tubular phallus (with the phallobase reaching the abdominal sternum $\mathrm{V}$ ). Additionally, larvae of Xiphocentronidae can be distinguished by a fusion of the tibia and tarsus of each leg (separated in Psychomyiidae) and by the extension of the mesopleuron anteriorly as a lobate process (absent in Psychomyiidae) (Barnard \& Dudgeon 1984). Currently, Xiphocentronidae comprises two subfamilies: Proxiphocentroninae Schmid, 1982, including the Oriental genus Proxiphocentron Schmid, 1982 only, which shares many plesiomorphic characters with Psychomyiidae, and Xiphocentroninae Schmid, 1982, grouping all other genera of the family.

The Neotropical fauna comprises 58 species in three genera: Cnodocentron Schmid, 1982, with 12 species from the southwestern USA to northern South America, as well as India and Southeast Asia; the exclusive Neotropical genera Machairocentron Schmid, 1982, with six species from Central America to northern South America, including Central Amazonia; Xiphocentron Brauer, 1870, with 46 extant species and two subspecies widely distributed in the Neotropics (Holzenthal \& Calor 2017).

Xiphocentron is the largest genus in the family and includes five subgenera: Glyphocentron Schmid, 1982 (two species), Rhamphocentron Schmid, 1982 (six species), Sphagocentron Schmid, 1982 (two species), Xiphocentron (five species), and Antillotrichia Banks, 1941 (31 species) (Holzenthal \& Calor 2017). Adults are small, generally black to dark brown, with pubescent forewings pointed at apex and covered by fine long dark setae, generally with a circular patch of white setae near the nygma. They are not commonly atracted to light traps since they have diurnal activity, which partially explains their scarcity in collections (Flint 1968; Schmid 1982). Larvae are found on rocks in fast-flowing water or, more commonly, on moist rocks at or above the water line (Holzenthal \& Calor 2017). The use of Malaise traps placed above flowing streams and hygropteric environments seems to be the most efficient method to capture specimens of xiphocentronid.

In Brazil, there are eight described species of Xiphocentron (Fig. 1), all placed in the subgenus Antillotrichia: X. (A.) acqualume Rocha, Dumas \& Nessimian, 2017, X. (A.) ilionea Schmid, 1982, X. (A.) jaguare Rocha, Dumas \& Nessimian, 2017, X. (A.) kamakan Vilarino \& Calor, 2015, $X$. (A.) maiteae Vilarino \& Calor, 2015, X. (A.) sclerothrix Pes \& Hamada, 2013 and X. (A.) steffeni (Marlier, 1964). Xiphocentron (A.) saltuum (Müller, 1921) is a nomen dubium described only from a larval mandible (Flint et al. 1999).

The subgenus Antillotrichia is very similar to Ramphocentron. It can be differenciated by three anal veins in the forewing (two in Ramphocentron) and the hindlegs with simple apical spurs (spurs distinctly enlarged in Ramphocentron) (Schmid 1982). In this paper, we describe four new species of Xiphocentron (Antillotrichia) from the Atlantic Forest in the Parque Nacional da Tijuca, a national park in Rio de Janeiro State, southeastern Brazil.

\section{Material and methods}

Specimens were collected between 2014 and 2017 in the Parque Nacional da Tijuca, an urban fragment of Atlantic Forest in the city of Rio de Janeiro, southeastern Brazil (Fig. 1), using Pennsylvania light traps (Frost 1957) and Malaise traps (Gressit \& Gressit 1962). The specimens were preserved in 96\% ethanol.

In order to observe the wing venation, the right wings were removed and observed under a stereo microscope on a black underground. Photographs of the wing venation and the spurs on the hind tibia 
were taken with a Leica Camera (DFC450) coupled to a Leica stereo microscope (M205C) and then digitized with Adobe Illustrator ${ }^{\circledR}$ CS6. To observe the internal structures, we removed the abdomens and cleared the genitalia following the standard methods outlined by Prather (2003) and Blahnik et al. (2007) using $85 \%$ lactic acid or a solution of $10 \% \mathrm{KOH}$. The prepared genitalia were transferred to microvials with $96 \%$ ethanol. They were examined with optical microscopy at a magnification of 100-400. Structures were traced in pencil using a compound microscope (Carl Zeiss, model Axiolab) equipped with a drawing tube and then digitized with Adobe Illustrator ${ }^{\circledR}$ CS6. The morphological terminology for genitalia follows Nielsen (1957) and Schmid (1982). Terminology for wing venation follows the Comstock-Needham system as interpreted for Trichoptera by Mosely \& Kimmins (1953). The phallus in Xiphocentron shows very little variation, mostly concerning the degree of enlargement at

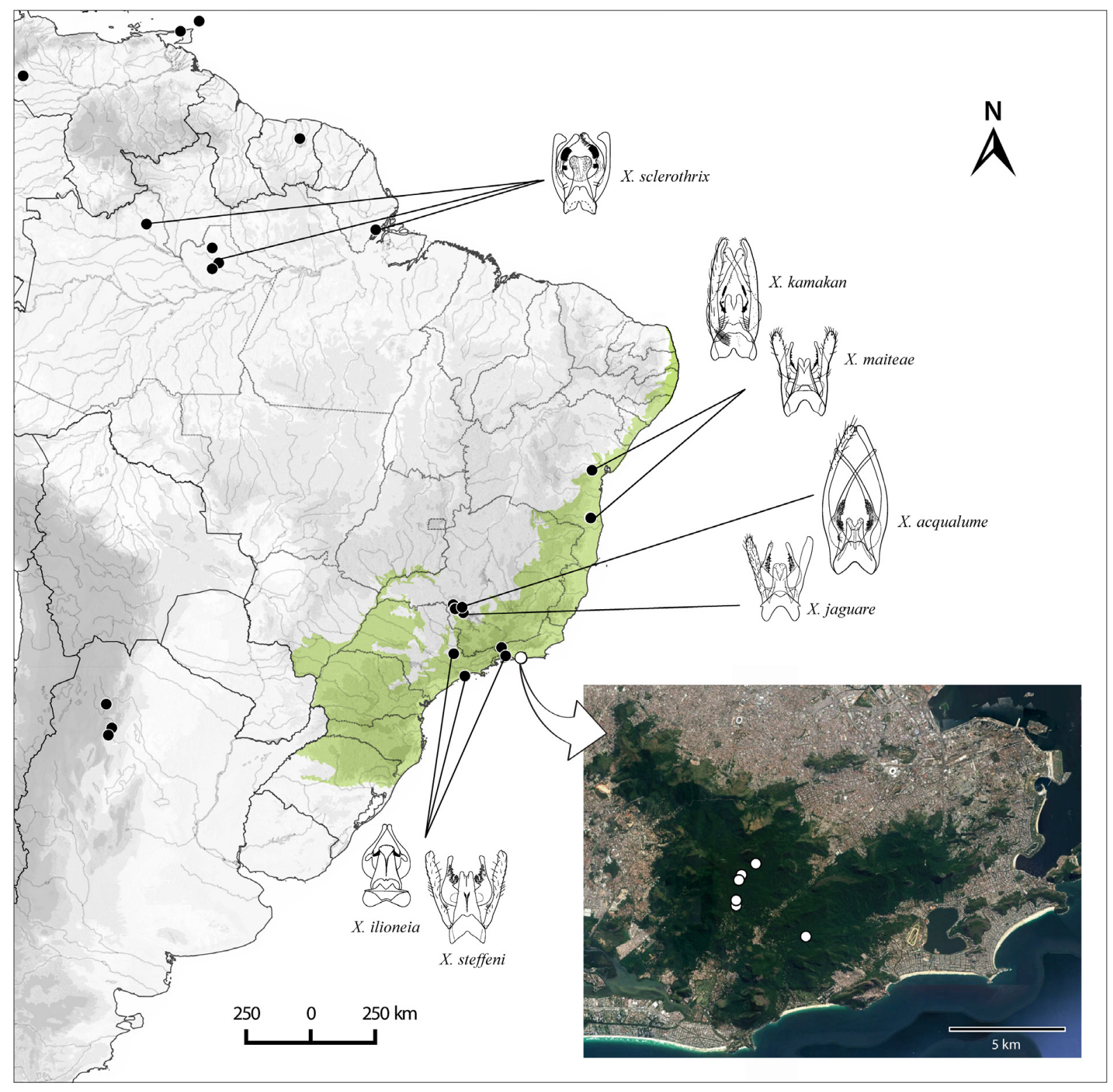

Fig. 1. Map showing the collecting sites at Parque Nacional da Tijuca (white circles) and distribution of Xiphocentron Brauer, 1870 in Brazil and part of South America (black circles). Species occurring in Brazil are figured in dorsal view (modified from Schmid 1982; Pes et al. 2013; Vilarino \& Calor 2015; Rocha et al. 2017). The Atlantic Forest biome is highlighted in green. 
the apex. Hence, the phallus is not depicted in most of the descriptions. Here, we present only the phallus of $X$. copacabana sp. nov. in full length as an example, for the other species we illustrate only the apex of the phallus. The glandular regions of the abdominal sternum $\mathrm{V}$ do not show any variation among the species here described either, so this structure is only depicted for X. copacabana sp. nov.

A distribution map was generated using the open source software QGIS v. 2.8.2. and a satellite photo from Google Earth (Image ${ }^{\circledR} 2017$ DigitalGlobe, ${ }^{\circledR} 2017$ Google, Image ${ }^{\circledR} 2017$ TerraMetrics).

The type specimens were deposited in the Coleção Entomológica Professor José Alfredo Pinheiro Dutra, Departamento de Zoologia, Universidade Federal do Rio de Janeiro, Rio de Janeiro, Brazil (DZRJ) and Museu de Zoologia, Universidade de São Paulo, São Paulo, Brazil (MZSP) as indicated in the species descriptions.

\title{
Results
}

\author{
Class Insecta Linnaeus, 1758 \\ Order Trichoptera Kirby, 1813 \\ Superfamily Psychomyioidea Ivanov, 2002 \\ Family Xiphocentronidae Ross, 1949 \\ Genus Xiphocentron Brauer, 1870
}

Xiphocentron (Antillotrichia) copacabana sp. nov. urn:lsid:zoobank.org:act:EFF2DFEE-1C2E-40D6-8DCD-E4E04854FCD2

Figs $2-3$

\section{Diagnosis}

The new species resembles $X$. maiteae in having the basoventral margin of the inferior appendages distinctly projected posterad. However, the new species differs by having a small mesal sclerite and two clusters of small spines on the inner face of the inferior appendages, one on the ventral projection and another subapically. In $X$. maiteae, the ventral projection has large dentate spines, and does not form these two clusters of small spines. Additionally, the new species has a broader posterior region on tergum IX and the apex of the phallus is not enlarged as in X. maiteae. They also are differentiated by the forewing venation: fork II is sessile in the new species, while it is peciolate in X. maiteae.

\section{Etymology}

The specific epithet refers to the beach at Copacabana, one of the most famous beaches in the world and located in the city of Rio de Janeiro.

\section{Material examined}

\section{Holotype}

BRAZIL: $\widehat{0}$, Rio de Janeiro State, Rio de Janeiro, Parque Nacional da Tijuca, Rio Archer, Cascata

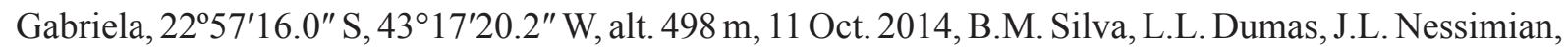
K.A. Estevão and F. Quintarelli leg. (DZRJ 7334).

\section{Paratype}

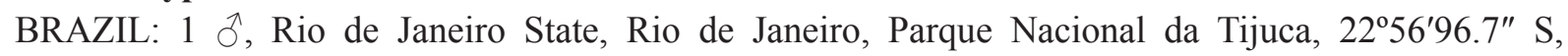
$43^{\circ} 17^{\prime} 67.9^{\prime \prime}$ W, alt. 786 m, Oct. 2016, L. Silveira, S. Vaz and B. Clarkson leg. (MZSP 5411). 


\section{Description}

\section{Adult}

Forewing length $3.2-3.5 \mathrm{~mm}(\mathrm{n}=2)$. Overall color (in alcohol) nearly uniformly medium brown. Tibial spur formula 2-4-3. Hind tibia apical spurs not modified (Fig. 2A). Forewings covered with fine, short, brown setae, with opaque region on anterior margin between Sc and R1 veins. Wing venation (Fig. 2B). Forewings: forks II and IV present; Sc reaching costa; fork II sessile starting in the discoidal cell; thyridial cell opened; fake vein present between $\mathrm{M}$ and $\mathrm{Cu} 1 \mathrm{a}+\mathrm{b}$; two anal veins are present. Hind wings: forks II and V present; fake veins present; Rs with three branches R2+3, R4 and R5; R1 absent. Abdominal sternum $\mathrm{V}$ bearing a pair of mammiform glandular regions (Fig. 2C).

\section{Male genitalia (Fig. 3A-F)}

Tergum IX, in lateral view (Fig. 3A), saddle-like, dorsally as broad as ventrally, dorsal margin undulated, anteroventral margin rounded, dorsal region of posterior margin produced posterad, forming a lobe; in dorsal view (Fig. 3B), anterior margin with a deep V-shaped central incision; posterolateral margins rounded; posterior margin squarely projected, apex subtruncated, slightly convex.

Sternum IX, in lateral view (Fig. 3A), dorsal margin straight, anterior margin medially with a medial apodeme, ventrally with an acute indentation, ventral margin rounded at base, posterior margin rounded; apodeme finger-like, apically rounded; in ventral view (Fig. 3C), posterior margin rounded, with a shallow rounded mesal incision, anterior margin straight, lateral apodemes longer than half-
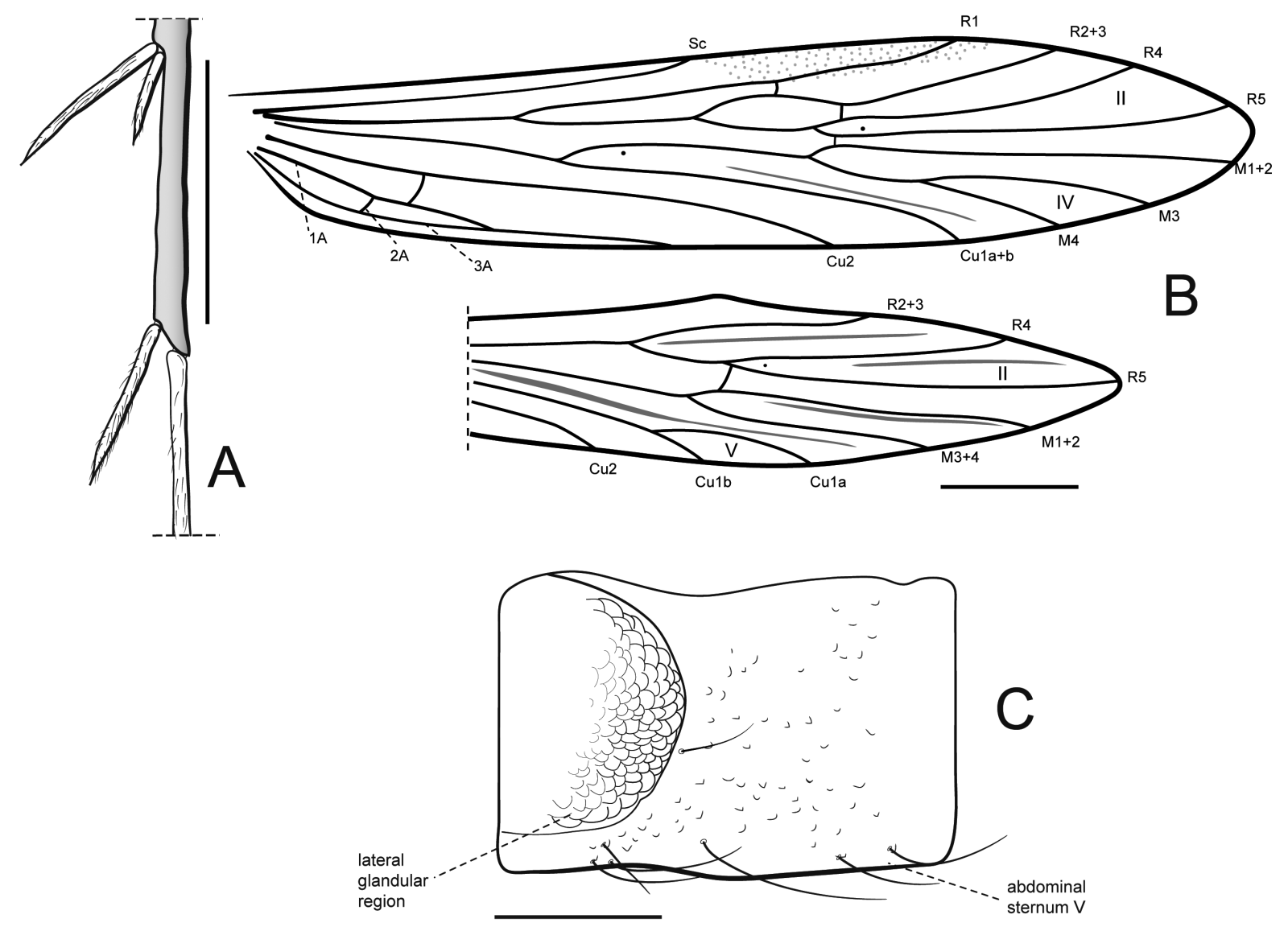

Fig. 2. Xiphocentron (Antillotrichia) copacabana sp. nov., holotype, adult, ${ }^{\lambda}$. A. Tibial spurs of the hind leg. B. Right wings, dorsal view. C. Glandular region of abdominal sternum V, left lateral. Scale bars: $\mathrm{A}-\mathrm{B}=0.5 \mathrm{~mm} ; \mathrm{C}=0.1 \mathrm{~mm}$. 

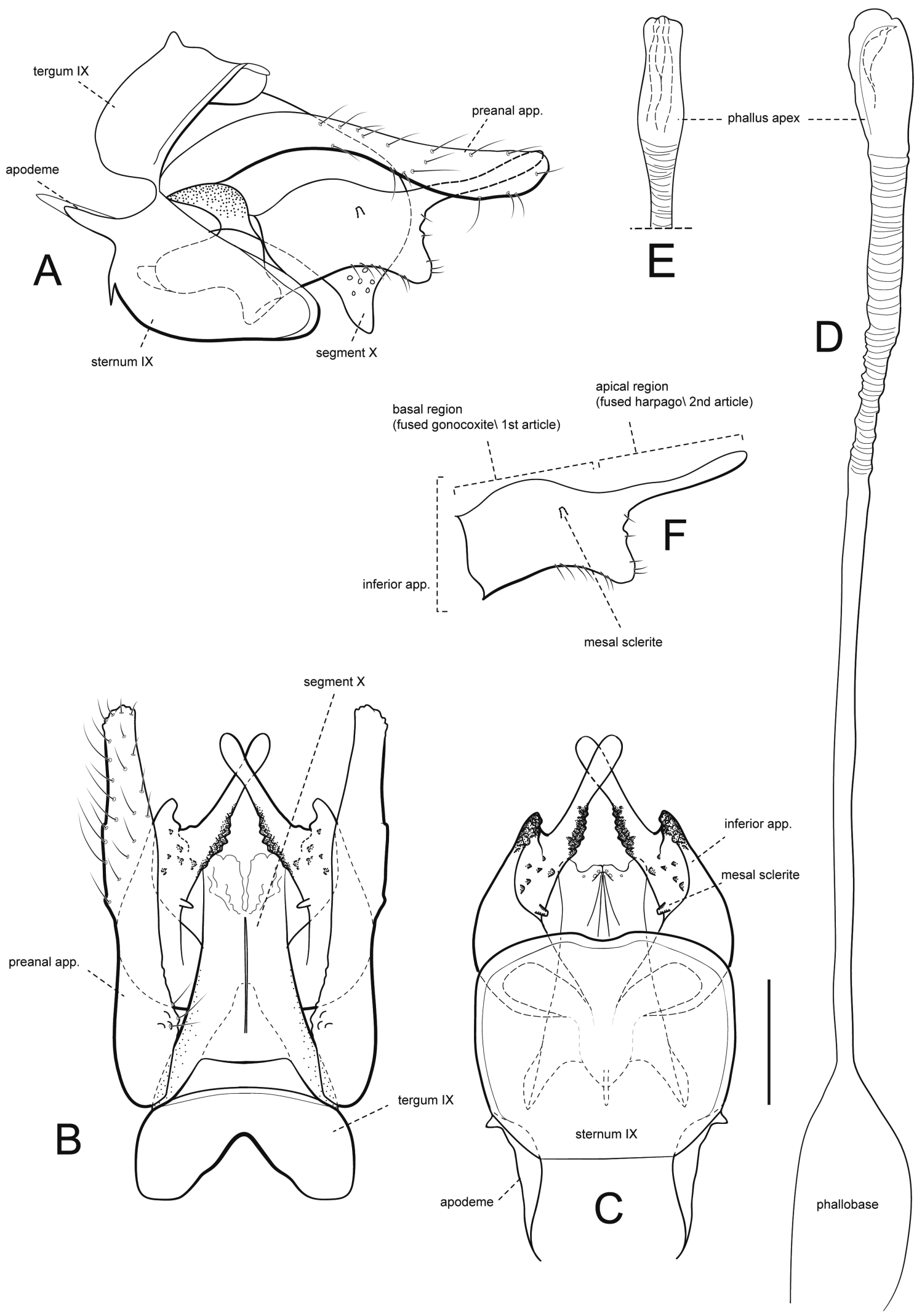

Fig. 3. Xiphocentron (Antillotrichia) copacabana sp. nov., holotype, adult, $\widehat{\jmath}$, genitalia. A. Left lateral view. B. Dorsal view. C. Ventral view. D. Phallus in full length, left lateral view. E. Phallus, apex in dorsal view. F. Detail of inferior appendage, left lateral view. Scale bar $=0.1 \mathrm{~mm}$. 
length of sternum IX, strongly tapered apically. Segment X semi-membranous; in lateral view (Fig. 3A), elongated, apicodorsally rounded, apicoventrally projected; in dorsal view (Fig. 3B), wider basally, narrower apically, closed all over its length, medially with a sclerotized band, apex split into two lobes, posterolateral margins slightly projected, truncated.

Preanal appendages elongated, about twice as long as segment X, setose; in lateral view (Fig. 3A), basally directed posterodorsally, slightly narrowed and bent posterad at mid-length, apex rounded; in dorsal view (Fig. 3B), enlarged at mid-length, apex slightly crenulated. Inferior appendages with articles completely fused (Fig. 3F); basal region, in lateral view (Fig. 3A), broad, ventral margin distinctly produced; apical region as long as the basal region, slender; in dorsal view (Fig. 3B), apex slightly inflated; inner face with sparse spines on the basal region, and cluster of small spines on projected posteroventral margin and subapically on apical region; mesal sclerite small, slightly larger than sparse spines of basal region.

Phallus tubular, long and slender, in lateral view (Fig. 3D), apex about twice as broad as the base; in dorsal view (Fig. 3E), apex not enlarged, semi-membranous.

Xiphocentron (Antillotrichia) maracanan sp. nov. urn:1sid:zoobank.org:act:757CC480-9BF8-4E4F-8661-271FD6FC38C2

Figs $4-5$

\section{Diagnosis}

The new species is characterized by a strongly bent inferior appendage (at an angle of about $90^{\circ}$ between the base and the apex), with a set of small spines, ranging from the mesal sclerite to near the apex. Moreover, tergum IX has a posterior margin forming a slightly concave central incision with acute sides. The new species has a similar forewing venation as in X. cobacabana sp. nov., with a sessile fork II. The genitalia of the two species are, however, very different.

\section{Etymology}

The specific epithet refers to the soccer stadium Estádio Jornalista Mário Filho, located in the city of Rio de Janeiro, and popularly known as Maracanã.

\section{Material examined}

\section{Holotype}

BRAZIL: $\widehat{\jmath}$, Rio de Janeiro State, Rio de Janeiro, Parque Nacional da Tijuca, Rio Taquaruçú (below

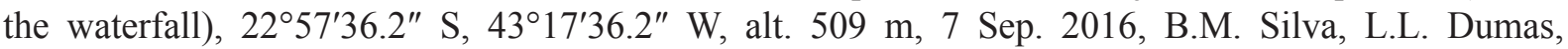
J.L. Nessimian and F. Quintarelli leg. (DZRJ 7335).

\section{Paratype}

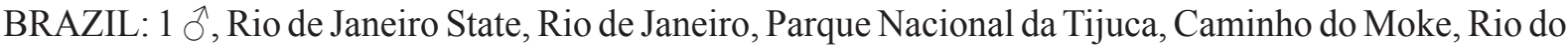
Moke, 2258'29.8" S, 43¹5'52.7" W, alt. 355 m, 6 Feb. 2017, A.L.R. Silva, B.M. Silva, J.L. Nessimian, A.S. Nascimento and A.L.H. Oliveira leg. (MZSP 5412).

\section{Description}

\section{Adult}

Forewing length $3.7-4.2 \mathrm{~mm}(\mathrm{n}=2)$. Overall color (in alcohol) nearly uniformly medium brown. Tibial spur formula 2-4-3. Hind tibia apical spurs not modified (Fig. 4A). Forewings covered with uniformly fine brown setae, with opaque region on anterior margin between Sc and R1 veins. Wing venation (Fig. 4B). Forewings: forks II and IV present; Sc reaches costa and then curves meeting R1; fork II 
sessile starting in discoidal cell; thyridial cell closed; two anal veins present. Hind wings: forks II and V present; Rs with three branches R2+3, R4 and R5; R1 absent. Abdominal sternum V bearing pair of mammiform glandular regions.

\section{Male genitalia (Fig. 5A-E)}

Tergum IX, in lateral view (Fig. 5A), ventrally broader, dorsal margin straight, anteroventral margin rounded, dorsal region of posterior margin projected posterad, forming a lobe; in dorsal view (Fig. 5B), anterior margin with deep V-shaped central incision, posterior margin mesally projected, with slightly concave central incision forming acute edges. Sternum IX, in lateral view (Fig. 5A), dorsal margin rounded, anterior margin with medial apodeme, ventrally with acute indentation, ventral margin rounded, posterior margin truncate; apodeme apically acuminate; in ventral view (Fig. 5C), with posterior margin produced, bearing medial V-shaped incision, anterior margin straight, lateral apodemes about half as long as sternum IX, strongly tapered apically. Segment X semi-membranous; in lateral view (Fig. 5A), elongated, apicodorsally truncated, apicoventrally produced; in dorsal view (Fig. 5B), wider apically, constricted near mid-length, closed all over its length, medially with sclerotized band, apex split into two lobes; in ventral view (Fig. 5C), concave apically, ventral region of segment cleft apically.

Preanal appendages elongated, about $1.5 \times$ as long as segment X, setose; in lateral view (Fig. 5A), basally directed posterodorsally, then bent posterad near mid-length, enlarged and rounded apically; in dorsal view (Fig. 5B), slightly enlarged basally, slightly tapered apically, apex obtuse. Inferior appendages with articles completely fused; basal region, in lateral view (Fig. 5A), broad, bent $90^{\circ}$ with respect to apical region, posteroventral margin not produced; apical region as long as basal region, slender, in dorsal view (Fig. 5B), with apex slightly enlarged; inner face with spines ranging from mesal sclerite until apical region; in lateral view (Fig. 5A), spines in a row on ventral margin of apical region; mesal sclerite small, with basal spine (only clearly visible in ventral view).

Phallus tubular, long and slender, in lateral view (Fig 5D), apex almost as broad as the base; in dorsal view (Fig 5E), apex not enlarged, semi-membranous, cleft apically.

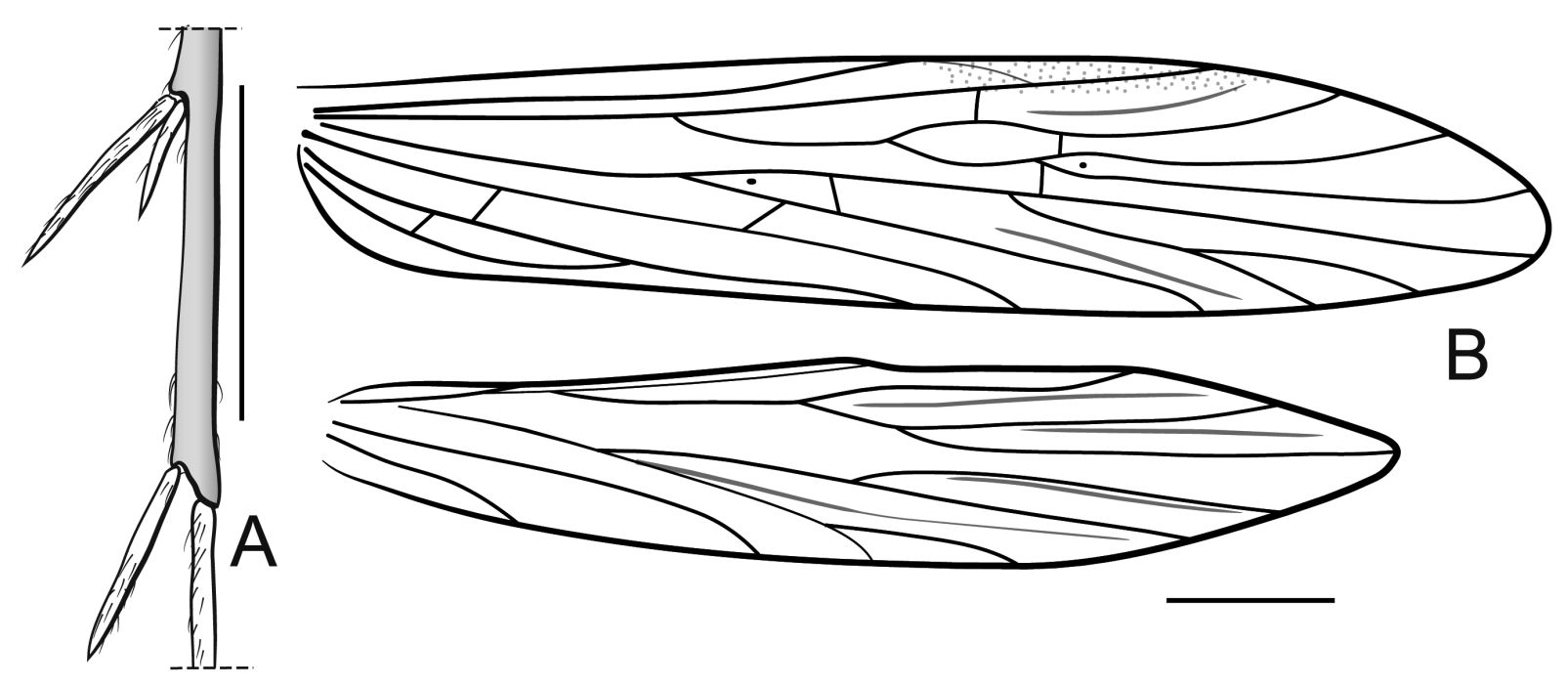

Fig. 4. Xiphocentron (Antillotrichia) maracanan sp. nov., holotype, adult, $\partial$. A. Tibial spurs of the hind leg. B. Right wings, dorsal view. Scale bars $=0.5 \mathrm{~mm}$. 


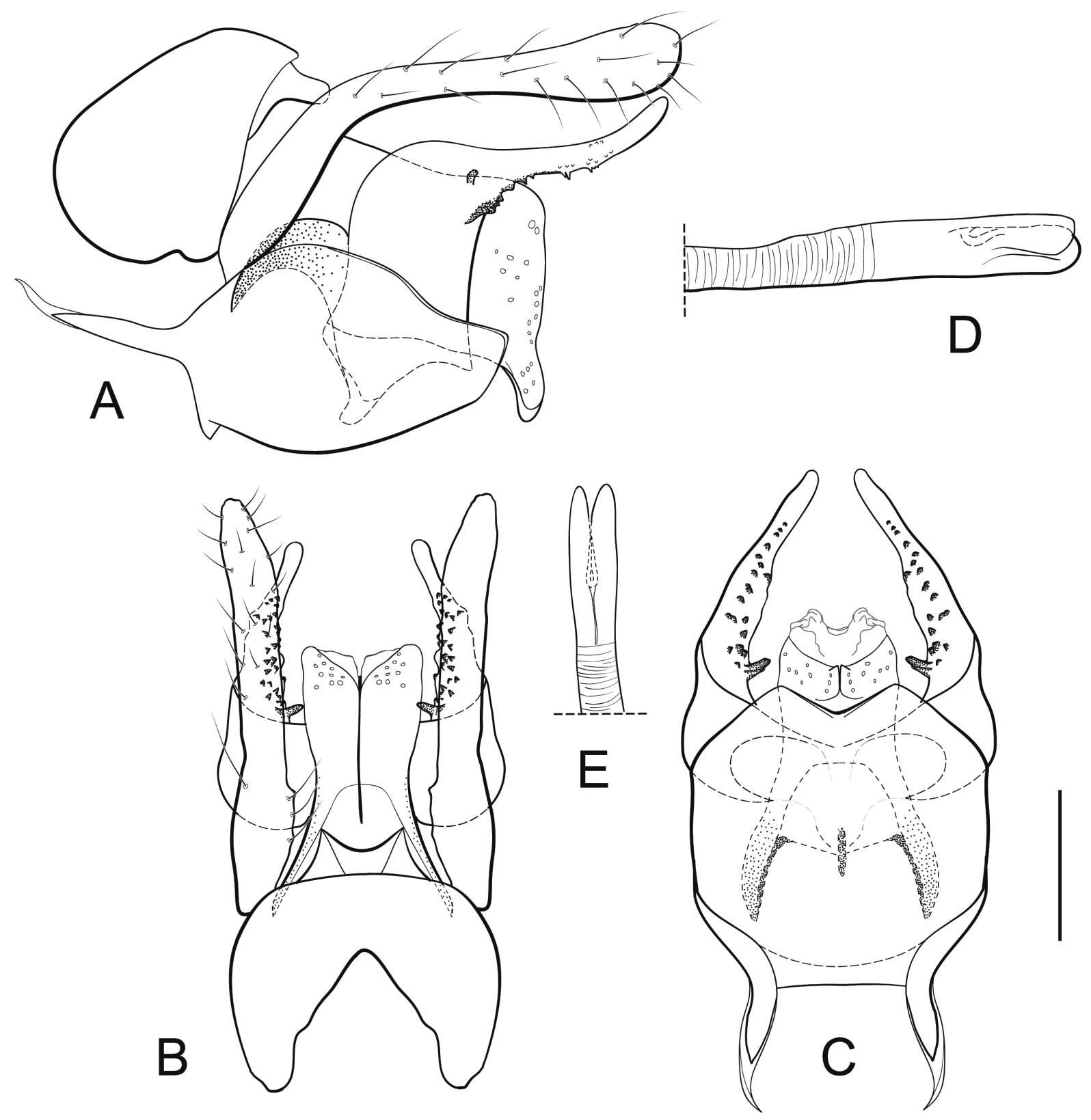

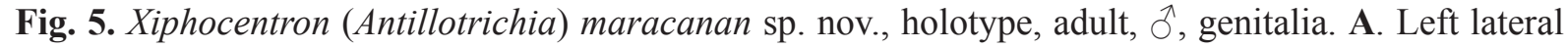
view. B. Dorsal view. C. Ventral view. D. Phallus apex, left lateral view. E. Phallus, apex in dorsal view. Scale bar $=0.1 \mathrm{~mm}$.

Xiphocentron (Antillotrichia) redentor sp. nov. urn:1sid:zoobank.org:act:0D373C30-D012-49BD-867C-53CF480CFBE6

Figs 6-7

\section{Diagnosis}

The wing venation of the new species is similar to that of $X$. tijuca sp. nov., having a peciolate fork II, with the nygma outside the fork. They differ, however, in the morphology of the genitalia. In X. redentor sp. nov., the inferior appendages have a linear row of broad spines, ranging from the basal region to 
subapically, while in $X$. tijuca sp. nov. they have only four spines mesally below the mesal sclerite. The preanal appendages are straight subbasaly and not produced as in X. tijuca sp. nov. Moreover, tergum IX in the new species has a produced posterior margin, forming rounded lobes, while in $X$. tijuca sp. nov. the lobes are very shallow.

\section{Etymology}

The specific epithet refers to the Cristo Redentor, an Art Deco statue of Jesus Christ, located at the peak of Corcovado in the Tijuca National Park, overlooking the city of Rio de Janeiro. The statue is listed as one of the New Seven Wonders of the World.

\section{Material examined}

\section{Holotype}

BRAZIL: ${ }^{\lambda}$, Rio de Janeiro State, Rio de Janeiro, Parque Nacional da Tijuca, Gruta Paulo e Virgínia, Rio Archer, 2257'15.3" S, 4317'29.9" W, alt. 593 m, 11 Nov. 2015, B.M. Silva, L.L. Dumas, J.L. Nessimian and F. Quintarelli leg. (DZRJ 7336).

\section{Paratypes}

BRAZIL: 2 $\partial^{\Uparrow}$, Rio de Janeiro State, Rio de Janeiro, Parque Nacional da Tijuca, Rio Taquaruçú ('abaixo

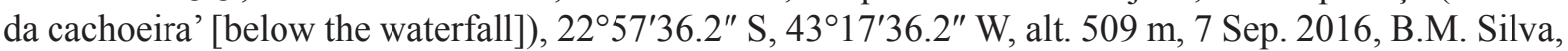
L.L. Dumas, J.L. Nessimian and F. Quintarelli leg. (DZRJ 7337); $1 \hat{\delta}$, same data as for preceding (MZSP 5413).

\section{Description}

\section{Adult}

Forewing length $4.0 \mathrm{~mm}(\mathrm{n}=4)$. Overall color (in alcohol) nearly uniformly medium brown. Tibial spur formula 2-4-3. Hind tibia apical spurs not modified (Fig. 6A). Forewings covered with uniformly fine, brown setae, with opaque region on anterior margin between Sc and R1. Wing venation (Fig. 6B). Forewings: forks II and IV present; Sc reaching C; fork II petiolated, nygma outside fork; thyridial cell closed; two anal veins present. Hind wings: forks II and V present; Rs with three branches R2+3, R4 and R5; R1 absent. Abdominal sternum $\mathrm{V}$ bearing pair of mammiform glandular regions.

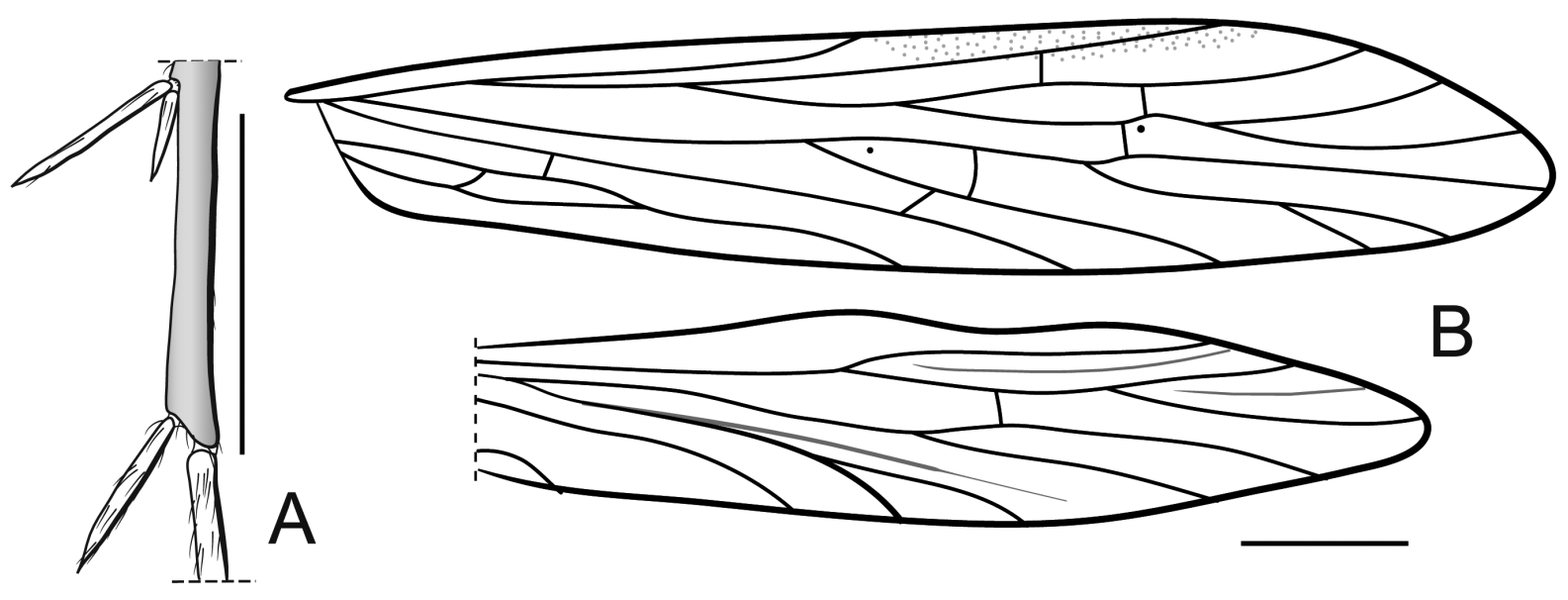

Fig. 6. Xiphocentron (Antillotrichia) redentor sp. nov., holotype, adult, ${ }^{\lambda}$. A. Tibial spurs of the hind leg. B. Right wings, dorsal view. Scale bar $=0.5 \mathrm{~mm}$. 


\section{Male genitalia (Fig. 7A-E)}

Tergum IX, in lateral view (Fig. 7A), ventrally broader, anteroventral margin rounded, posterior margin, ventral region roundly produced, dorsal region produced posterad; in dorsal view (Fig. 7B), anterior margin presenting deep V-shaped central incision, posterior margin projected with small U-shaped central incision forming rounded lobes; posterolateral margins projected rounded. Sternum IX, in lateral view (Fig. 7A), with dorsal margin almost straight, anterior margin with medial apodeme, ventrally straight without acute indentation, ventral margin rounded, posterior margin rounded; apodeme apically

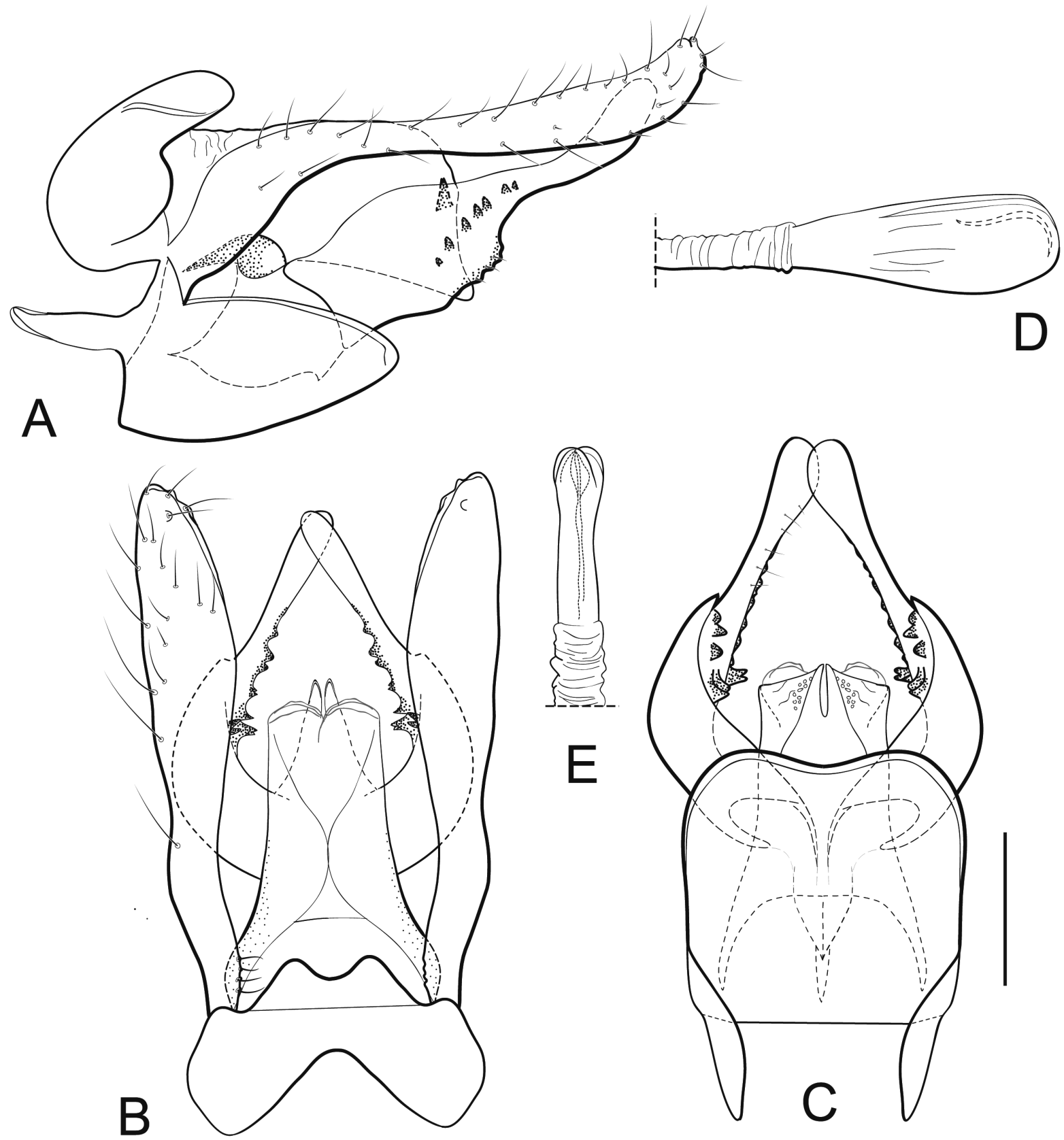

Fig. 7. Xiphocentron (Antillotrichia) redentor sp. nov., holotype, adult, $\widehat{\partial}$, genitalia. A. Left lateral view. B. Dorsal view. C. Ventral view. D. Phallus apex, left lateral view. E. Phallus, apex in dorsal view. Scale bar $=0.1 \mathrm{~mm}$. 
acuminate; in ventral view (Fig. 7C), posterior margin with shallow medial concavity, anterior margin straight, lateral apodemes half as long as sternum IX, tapered apically.

Segment X semi-membranous; in lateral view (Fig. 7A), elongated, apicodorsally rounded, apicoventrally produced; in dorsal view (Fig. 7B), wider basally, closed all over its length, apex split into two small rounded lobes; in ventral view (Fig. 7C), truncate apically, ventral region of segment triangular, cleft apically.

Preanal appendages elongated, about twice as long as segment $\mathrm{X}$ and setose; in lateral view (Fig. 7A), basally directed posterodorsally, then bent posterad, constricted at mid-length, apex rounded; in dorsal view (Fig. 7B), narrower at base and sinuous, enlarged subapically, apex rounded, slightly rugous. Inferior appendages with articles completely fused; basal region, in lateral view (Fig. 7A), broad, posteroventral margin crenated, not produced; apical region slightly longer than basal region, slender, in dorsal view (Fig. 7B), with apex strongly enlarged; inner face with row of seven broad spines, ranging from basal region to subapical region; mesal sclerite small, bearing two or three points at apex.

Phallus tubular, long and slender; in lateral view (Fig. 7D), apex length about three times as long as base; in dorsal view (Fig. 7E), apex not enlarged, semi-membranous.

Xiphocentron (Antillotrichia) tijuca sp. nov.

urn:1sid:zoobank.org:act:414E4BF3-15E5-44EB-890B-3EDE51ED8173

Figs $8-9$

\section{Diagnosis}

The new species can be differentiated from its congeners by the preanal appendage with a subbasal region markedly produced mesad when observed dorsally. Moreover, in ventral view, the apical region of the inferior appendage is subapically thin, then enlarged apically and bent dorsad. The tergum IX is distinct by the soft and shallow incision on the anterior margin, which is deeper in most of the other species.

\section{Etymology}

The specific epithet refers to the Parque Nacional da Tijuca, a tropical rainforest in the city of Rio de Janeiro where the specimens were collected.

\section{Material examined}

\section{Holotype}

BRAZIL: ${ }^{\lambda}$, Rio de Janeiro State, Rio de Janeiro, Parque Nacional da Tijuca, Gruta Paulo e Virgínia, Rio Archer, 22 ${ }^{\circ} 7^{\prime} 15.3^{\prime \prime}$ S, 4317'29.9" W, alt. 593 m, 11 Nov. 2015, B.M. Silva, L.L. Dumas, J.L. Nessimian and F. Quintarelli leg. (DZRJ 7338).

\section{Paratypes}

BRAZIL: 1 ${ }^{\lambda}$, Rio de Janeiro State, Rio de Janeiro, Parque Nacional da Tijuca, Cachoeira das Almas,

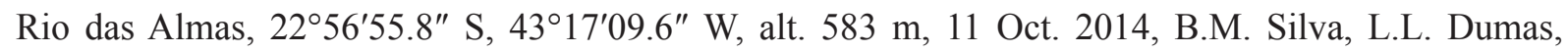
J.L. Nessimian, K.A. Estevão and F. Quintarelli leg, (DZRJ 7339); 1 ô, Rio de Janeiro, Parque Nacional da Tijuca, Rio Cova da Onça, 2257'45.2" S, 43¹7'36.5" W, alt. 494 m, 12 Nov. 2015, B.M. Silva, L.L. Dumas, J.L. Nessimian and F. Quintarelli leg. (MZSP 5414). 


\section{Description}

\section{Adult}

Forewing length $3.5 \mathrm{~mm}(\mathrm{n}=3)$. Overall color (in alcohol) nearly uniformly medium brown. Tibial spur formula 2-4-3. Hind tibia apical spurs not modified (Fig. 8A). Forewings covered with uniformly fine, brown setae, with an opaque region on anterior margin between Sc and R1 veins. Wing venation (Fig. 8B). Forewings: forks II and IV present; Sc reaching Costa; fork II petiolated, nygma outside fork; thyridial cell closed; two anal veins present. Hind wings: forks II and V present; Rs with three branches R2+3, R4 and R5; R1 absent. Abdominal sternum V bearing pair of mammiform glandular regions.

\section{Male genitalia (Fig. 9A-E)}

Tergum IX, in lateral view (Fig. 9A), dorsally short and ventrally broad, anteroventral margin undulated, posterior margin rounded, dorsal region produced posterad, forming lobe; in dorsal view (Fig. 9B), with anterior margin presenting a shallow concave incision, posterior margin projected with shallow concave central incision; posterolateral margins rounded. Sternum IX, in lateral view (Fig. 9A), with dorsal margin undulated, anterior margin with medial apodeme, ventrally acutely angled, but without indentation, ventral margin rounded, posterior margin truncate; apodeme apically acuminate; in ventral view (Fig. 9C), posterior margin produced, with medial broad and shallow concave incision, anterior margin straight, lateral apodemes half as long as sternum IX, tapered apically. Segment X semi-membranous; in lateral view (Fig. 9A), elongated, truncated apically, apicoventrally produced; in dorsal view (Fig. 9B), wider basally, closed through all over its length, membranous basally and medially, apex split into two lateral lobes; in ventral view (Fig. 9C), ventral region of segment as two triangular lobes near apex, lobes touching each other apically. Preanal appendages elongated, about $1.5 \times$ as long as segment $\mathrm{X}$, setose; in lateral view (Fig. 9A), basally directed posterodorsally, then bent posterad, constricted at mid-length, strongly enlarged apically, apex rounded, slightly crenulated; in dorsal view (Fig. 9B), with subbasal region produced medially, subapical region slightly enlarged, tapering to rounded apex. Inferior appendages with articles completely fused; basal region, in lateral view (Fig. 9A), broad, ventral margin not produced; apical region as long as basal region, slender, very thin subapically, apex bent dorsally, enlarged; inner face with smooth undulations ranging from mesal sclerite to near apex, mesally with four spines below mesal sclerite; mesal sclerite small. Phallus tubular,

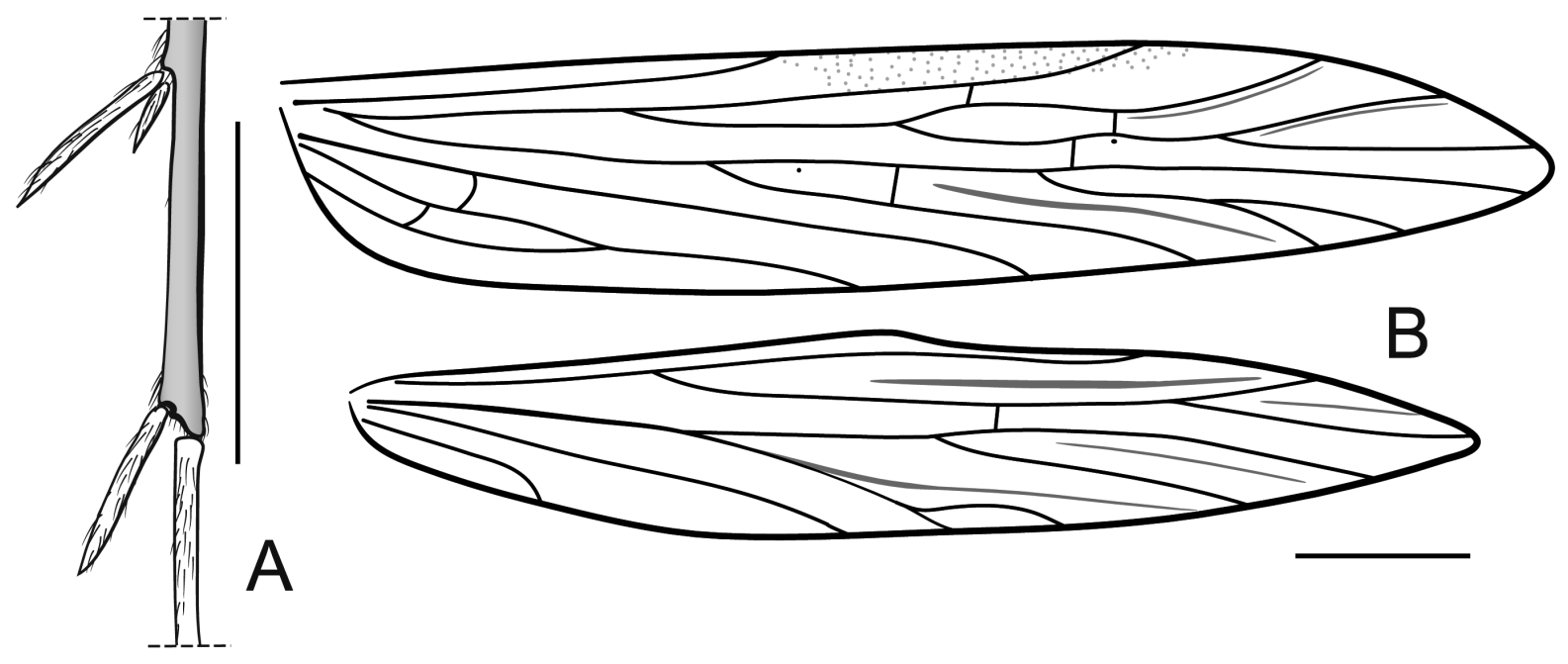

Fig. 8. Xiphocentron (Antillotrichia) tijuca sp. nov., holotype, adult, ô. A. Tibial spurs of the hind leg. B. Right wings, dorsal view. Scale bars $=0.5 \mathrm{~mm}$. 
long and slender; in lateral view (Fig. 9D), apex about twice as broad as base; in dorsal view (Fig. 9E), apex not enlarged, semi-membranous.

\section{Discussion}

Xiphocentron (Antillotrichia) is the only subgenus of the family occurring in South America, now with 18 species recorded in the region (with species from Argentina, Brazil, Colombia, Guiana and Venezuela). Type series usually contain a low number of specimens, because of the weak attraction to standard light traps, when malaise traps are not used. This aspect probably explains the few known records of the group in Brazil and it can lead to an underestimated diversity. Most of the species of X. (Antillotrichia)
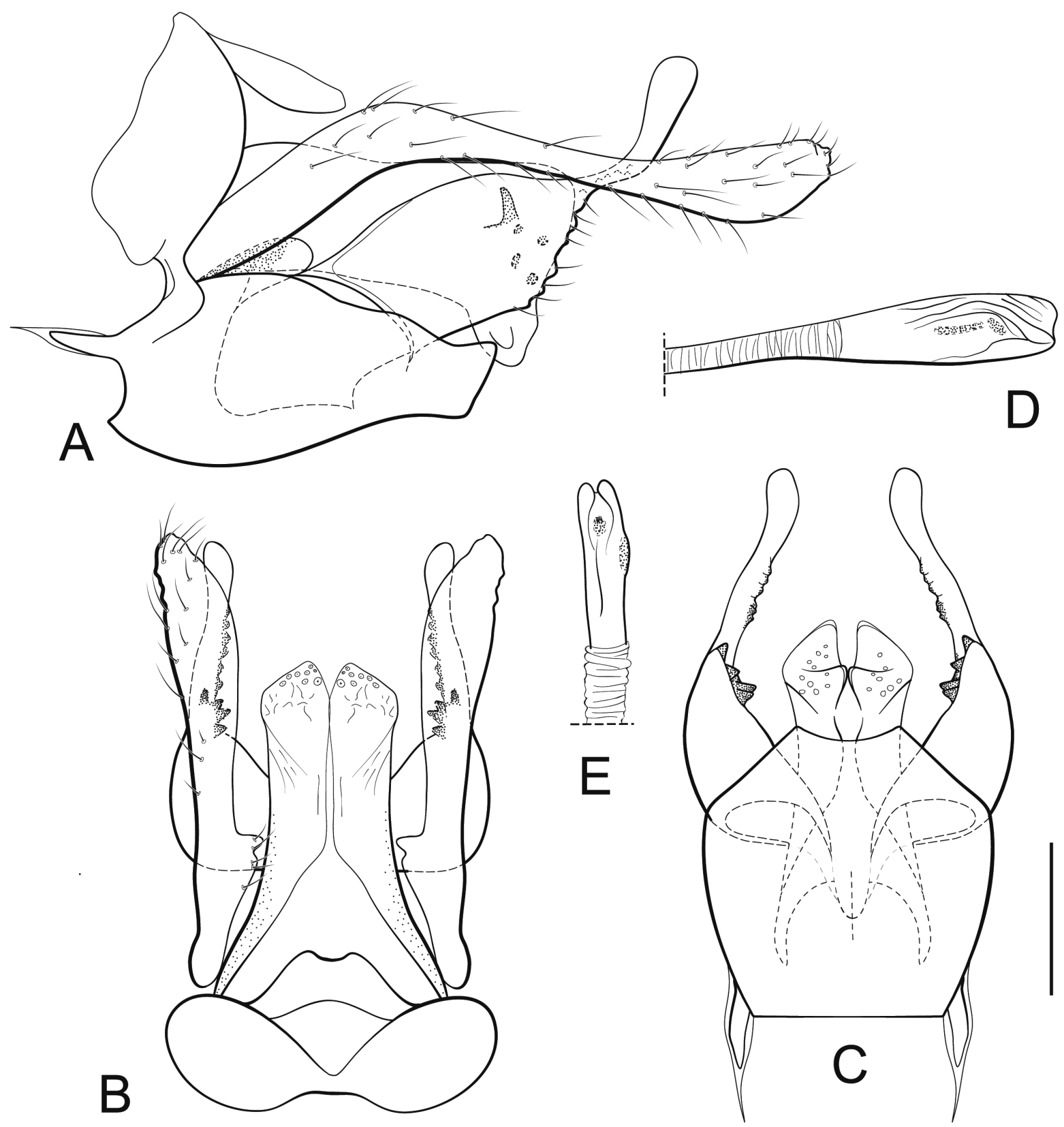

Fig. 9. Xiphocentron (Antillotrichia) tijuca sp. nov., holotype, adult, $\hat{\jmath}$, genitalia. A. Left lateral view. B. Dorsal view. C. Ventral view. D. Phallus apex, left lateral view. E. Phallus, apex in dorsal view. Scale bar $=0.1 \mathrm{~mm}$. 
and other subgenera of Xiphocentron have a forewing with fork II (R4 and R5) sessile (Schmid 1982), although all the species previously known from the Atlantic Forest Region present this fork petiolate. Xiphocentron copacabana sp. nov. and X. maracanan sp. nov. are the first species recorded in this region having a fork II sessile. Xiphocentron (A.) sclerothrix, the only species from the Brazilian Amazon Basin in the subgenus, is more similar to the other species from the Antilles, having long spines in the inferior appendage and a fork II sessile, as is common. All the species here described have inferior appendages with a very simple mesal sclerite, differing from that in X. kamakan, X. ilionea and X. steffeni, where it is distinctly covered with spines.

\section{Acknowledgements}

This work is supported by the Conselho Nacional de Desenvolvimento Científico e Tecnológico (CNPq), the Fundação de Amparo à Pesquisa do Estado do Rio de Janeiro (FAPERJ) and the Coordenação de Aperfeiçoamento de Pessoal de Nível Superior (CAPES). The Instituto Brasileiro do Meio Ambiente e dos Recursos Naturais Renováveis (IBAMA), the Instituto Chico Mendes de Conservação da Biodiversidade (ICMBio), the Instituto Estadual do Ambiente (INEA) and all collaborating Conservation Units are also thanked for issuing collecting permits (14591-16; 52246-1 ICMBio; E-07/002.7987/2014 INEA).

\section{References}

Barnard P.C. \& Dudgeon D. 1984. The larval morphology and ecology of a new species of Melanotrichia from Hong Kong (Trichoptera: Xiphocentronidae). Aquatic Insects: International Journal of Freshwater Entomology 6 (4): 245-252. https://doi.org/10.1080/01650428409361190

Blahnik R.J., Holzenthal R.W. \& Prather A.L. 2007. The lactic acid method for clearing Trichoptera genitalia. In: Bueno-Soria J., Barba-Alvarez R. \& Armitage B.J. (eds) Proceedings of the 12th International Symposium on Trichoptera: 9-14. The Caddis Press, Columbus, Ohio.

Edwards S.W. 1961. The immature stages of Xiphocentron mexico (Trichoptera). Texas Journal of Science 13: 51-56.

Flint O.S. Jr. 1968. The Trichoptera (caddisflies) of the Lesser Antilles. Proceedings of the United States National Museum 125 (3665): 1-86. Available from https://biodiversitylibrary.org/page/15386361 [accessed 25 Apr. 2018].

Flint O.S. Jr., Holzenthal R.W. \& Harris S.C. 1999. Nomenclatural and systematic changes in the Neotropical caddisflies (Insecta: Trichoptera). Insecta Mundi 13: 73-84.

Frost S.W. 1957. The Pennsylvania insect light trap. Journal of Economic Entomology 50: 287-292. https://doi.org/10.1093/jee/50.3.287

Gressitt J.L. \& Gressitt M.K. 1962. An improved Malaise trap. Pacific Insects 4: 87-90.

Holzenthal R.W. \& Calor A.R. 2017. Catalog of the Neotropical Trichoptera (Caddisflies). ZooKeys 654: 1-566. https://doi.org/10.3897/zookeys.654.9516

Mosely M.E. \& Kimmins D.E. 1953. The Trichoptera of Australia and New Zealand. Trustees of the British Museum (Natural History), London. https://doi.org/10.5962/bhl.title.118696

Nielsen A. 1957. A comparative study of the genital segments and their appendages in male Trichoptera. Biologiske Skrifter, Danske Videnskabernes Selskab 8 (5): 1-159.

Pes A.M., Hamada N., Nessimian J.L. \& Soares C.C. 2013. Two new species of Xiphocentronidae (Trichoptera) and their bionomics in Central Amazonia, Brazil. Zootaxa 3636 (4): 561-574. https://doi.org/10.11646/zootaxa.3636.4.4 
Prather A.L. 2003. Revision of the Neotropical caddisfly genus Phylloicus (Trichoptera: Calamoceratidae). Zootaxa 275: 1-214. https://doi.org/10.11646/zootaxa.275.1.1

Rocha I.C., Dumas L.L. \& Nessimian J.L. 2017. Description of two new species of Xiphocentron Brauer, 1870 (Trichoptera: Xiphocentronidae) from southeastern Brazil. Tropical Zoology 30 (4): 170-177. https://doi.org/10.1080/03946975.2017.1362867

Ross H.H. 1949. Xiphocentronidae, a new family of Trichoptera. Entomological News 60: 1-7. Available from https://biodiversitylibrary.org/page/2583214 [accessed 25 Apr. 2018].

Schmid F. 1982. La famille des Xiphocentronidae (Trichoptera: Annulipalpia). Mémoires de la Société entomologique du Canada 121. Société entomologique du Canada, Toronto.

https://doi.org/10.4039/entm114121fv

Vilarino A. \& Calor A.R. 2015. New species of Xiphocentron Brauer, 1870 (Trichoptera: Xiphocentronidae) from Northeastern Brazil. Zootaxa 3914 (1): 46-54. https://doi.org/10.11646/zootaxa.3914.1.2

Manuscript received: 1 November 2017

Manuscript accepted: 15 January 2018

Published on: 5 June 2018

Topic editor: Gavin Broad

Desk editor: Kristiaan Hoedemakers

Printed versions of all papers are also deposited in the libraries of the institutes that are members of the EJT consortium: Muséum national d'Histoire naturelle, Paris, France; Botanic Garden Meise, Belgium; Royal Museum for Central Africa, Tervuren, Belgium; Natural History Museum, London, United Kingdom; Royal Belgian Institute of Natural Sciences, Brussels, Belgium; Natural History Museum of Denmark, Copenhagen, Denmark; Naturalis Biodiversity Center, Leiden, the Netherlands; Museo Nacional de Ciencias Naturales-CSIC, Madrid, Spain; Real Jardín Botánico de Madrid CSIC, Spain; Zoological Research Museum Alexander Koenig, Bonn, Germany. 